\title{
SCREENING FOR THE HOMOZYGOUS C.144DELC MUTATION IN AURKC GENE IN ALGERIAN INFERTILE MEN
}

\author{
REZGOUNE MOHAMED LARBI ${ }^{1,2}$, CHELLAT DJALILA $^{1,2}$, ABADI NOUREDDINE ${ }^{2}$, SATTA DALILA ${ }^{1,2}$ \\ ${ }^{1}$ Laboratory of Molecular and Cellular Biology, University Constantine I, Constantine, Algeria. ${ }^{2}$ Laboratory of Biology and Molecular \\ Genetic, University Hospital Center IBN-Badis, University Constantine III, Constantine, Algeria.
}

Email: rezgoune.mohamed.larbi@umc.edu.dz

Received: 26 September 2017, Revised and Accepted: 04 November 2017

ABSTRACT

Objective: Male infertility is a major health problem worldwide. Despite recent advances, the etiopathogenesis of spermatogenic failure remains largely uncertain. Aurora kinases, a family of serine/threonine kinases, consisting of Aurora A (AURKA), Aurora B (AURKB), and Aurora C (AURKC), are essential kinases for cell division through regulating mitosis and meiosis. The aim of this study was to investigate the frequency of c.144delC mutation in $A U R K C$ gene in infertile Algerian patients with abnormal sperm parameters.

Methods: In this study, 40 infertile men with impaired spermatogenesis (Azoospermia "AZOs,"' oligoasthenoteratospermia “OATs,"” Asthenospermia "ASTs") were recruited from Ibn Rochd clinic and Ibn Sina Laboratory, between 2008 and 2014. All men were of Algerian origin. DNA was extracted from peripheral blood. The third exon of the AURKC gene was amplified using polymerase chain reaction (PCR). Then, PCR products were sequenced using the big dye V1.1 terminator cycle sequencing in forward and reverse directions, and the results of sequenced segments were analyzed.

Results: Sequencing of the third exon of AURKC gene revealed the absence of c144delC mutation in all of the 40 patients screened.

Conclusion: Our data indicate that the AURKC c.144delC mutation must be investigated in infertile men with Macrozoospermia.

Keywords: AURKC, c144delC mutation, Male infertility, Sequencing, Algerian patients.

(C) 2018 The Authors. Published by Innovare Academic Sciences Pvt Ltd. This is an open access article under the CC BY license (http://creativecommons. org/licenses/by/4. 0/) DOI: http://dx.doi.org/10.22159/ajpcr.2018.v11i2.22783

\section{INTRODUCTION}

In recent decades, infertility has been considered to be a major public health problem worldwide. At present, male factors account for approximately $50 \%$ of cases which may exist alone or in conjunction with female factors $[1,2]$. Male infertility could be due to genetic and/or environmental factors. It is a complex problem where not only the genes but also the epigenetic factors play a key role. The alterations of epigenome have the same consequences as DNA mutations [3,4].

About $40 \%$ cases of male infertility are classified as idiopathic. These cases may be linked to genetic and genomic abnormalities. Chromosomal abnormalities and polymorphisms, microdeletions of the Azoospermia factor regions of the $\mathrm{Y}$ chromosome and cystic fibrosis transmembrane conductance regulator mutations have been demonstrated to be recurrent genetic causes of male infertility [2,5-8]. During the last years, more genes are implicated in male infertility leading to decline in the prevalence of idiopathic etiology $[8,9]$.

The genetic association between the c144delC mutation of the AURKC gene and male infertility with macrozoospermia is well established especially in North African patients [10,11].

Aurora kinase family is comprised regulators controlling chromosome segregation and condensation, centrosome duplication, G2/M transition, kinetochore attachment, and cytokinesis [12]. Three types of Aurora kinases are present in mammalian cells, AURKA, AURKB, and AURKC which have specific subcellular localizations and functions during the cell cycle. Aurora kinase C (AURKC) is a serine/threonine protein kinase and is expressed in both somatic neoplastic and germ cells [13-15].

Expression of Aurora C was first described in the testis [16] and is involved in chromatin condensation and proper attachment of homologous chromosomes during the first meiotic division [17-19]. In humans, the absence of a functional protein of AURKC is associated with male infertility $[10,11]$. Macrozoospermia in men with AURKC mutations is due to a failure to complete meiosis I (MI) [20].

On the basis of these considerations, we constructed this study to investigate the prevalence of c.144delC frameshift mutation in $A U R K C$ gene in a cohort of Algerian patients with impaired spermatogenesis and to clarify that this mutation is correlated with macrozoospermic phenotype.

\section{METHODS}

This study included a total of 40 subjects of Algerian origin referred to our laboratory and clinic for routine semen analysis. Peripheral blood samples were collected after explaining the study objectives. All patients gave their written informed consent. The study was approved by the local Ethics Committee.

\section{DNA extraction and DNA sequencing}

Leukocyte genomic DNA was extracted from blood samples using the standard method of salting out. DNA was quantified using a Nanodrop Spectrophotometer.

Polymerase chain reaction (PCR) was performed in a mixture of the following composition: 20-50 ng of genomic DNA, $1.5 \mathrm{mM} \mathrm{MgCl} 2,0.2 \mathrm{mM}$ dNTPs, $5.0 \mathrm{U} / \mu \mathrm{L}$ of Taq DNA polymerase (Bioline), and $100 \mathrm{ng} / \mu \mathrm{L}$ of each primer. The reaction was processed in a thermocycler as follows: Denaturation for $5 \mathrm{~min}$, at $95^{\circ} \mathrm{C}$, followed by 40 cycles of $30 \mathrm{~s}$, at $95^{\circ} \mathrm{C}$ (denaturation), $30 \mathrm{~s}$ at $66^{\circ} \mathrm{C}$, and $30 \mathrm{~s}$ at $72^{\circ} \mathrm{C}$ (extension).

Oligonucleotide primers used for PCR and minisequencing of AURKC exon 3: Forward, 5'-GACTTTCCCTCCGCCTACCCTAC 3' and reverse 5'GCTGGGCTCAGACGTCAAAGA 3'. 
Table 1: Sperm parameters and karyotype of analyzed patients $(n=40)$

\begin{tabular}{|c|c|c|c|c|c|}
\hline \multirow[t]{2}{*}{ Spermatic anomalies } & \multirow[t]{2}{*}{ Number of patients } & \multicolumn{3}{|l|}{ Sperm parameters (average) } & \multirow[t]{2}{*}{ Karyotype } \\
\hline & & Sperm count (million/mL) & Motility \% & Abnormal morphology \% & \\
\hline Azoospermia & 26 & 0 & - & - & $46, X Y$ \\
\hline Oligoasthenoteratozoospermia & 12 & $3.1 \pm 1.7$ & $4 \pm 0.06$ & $96 \pm 3.38$ & $46, X Y$ \\
\hline Asthenozoospermia & 2 & $36.11 \pm 0.015$ & $08.25 \pm 0.25$ & $47.5 \pm 0.5$ & $46, X Y$ \\
\hline
\end{tabular}

The PCR products were submitted to agarose gel electrophoresis $2 \%$, and afterward, the PCR products were purified using exonuclease I and phosphatase alkaline. These products were then sequenced (10-15 ng DNA template reaction) on automated DNA sequencher using the big dye V1.1 terminator cycle sequencing. To reveal the electrophoresis data, the peak signal was analyzed with sequencher 4.7.

\section{RESULTS}

Of the 40 cases, there were 26 cases with Azoospermia, 12 cases with Oligoasthenoteratozoospermia, and 2 cases with Asthenozoospermia (Table 1).

Direct sequencing of AURKC exon 3 revealed no mutation or c.144delC recurrent deletion in all patients screened (Fig. 1).

\section{DISCUSSION}

To knowledge, the present study is the first to investigate the frequency of C144del in a cohort of patients (40) with abnormal sperm parameters.

The c.144delC frameshift mutation is expected to have a severe impact on the protein function. Translation of the mutated gene produces a short 71-amino acid peptide that lacks nine-tenths of its kinase catalytic domain which makes it inactive leading to a defective meiosis with a blockage of spermatogenesis before the first meiotic divisions and the production of tetraploid large-headed multiflagellate spermatozoa [10].

Few studies examined the association of c.144del C of AURKC gene with male infertility. All of them concerned North African populations [10,11,21-25]. Therefore, further studies in different populations are essential.

Our study revealed no mutation in the AURKC exon 3 gene in all of the patients who were analyzed.

Previously, Dieterich et al., $[10,11]$ through two studies examined infertile men presenting typical spermatozoa mainly characterized by large heads, a variable number of tails and an increased chromosomal content and identified a common region of homozygosity harboring the aurora kinase $\mathrm{C}$ gene with a single nucleotide deletion in the AURKC coding sequence (c.144Cdel). All AURKC mutated patients either lived or originated from North Africa (Morocco, Tunisia, and Algeria). In agreement with our results, the same researchers $[10,11]$ investigated the frequency of this genetic defect by analyzing 30 patients (among these patients: 19 were Iranian patients, and nine were principally of French origin) who did not fit the criteria defined for typical large-headed patients. No mutations were identified in any of these 30 patients after double strand sequencing of the entire coding sequence and intron boundaries of the AURKC gene.

Moreover, Molinari et al. [26] reported a case of recurrent miscarriage in a patient affected by a variant phenotype of sperm macrocephaly syndrome. However, no mutations detectable by AURKC sequencing have been observed.

Two studies have been conducted in Morocco and confirmed the high prevalence of the homozygous mutation c.144delC in the teratozoospermia with large-headed spermatozoa [22,24]. Eloualid et al. screened 326 idiopathic infertile patients for the presence of the AURKC c.144delC mutation and found a frequency of $2.14 \%$ in patients

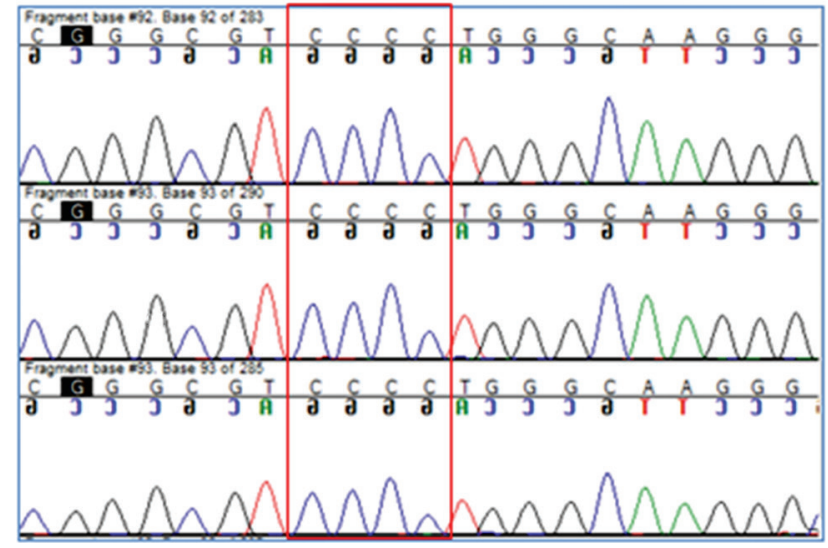

Fig. 1: Electrophoregram showing part of AURKC exons 3 from 3 subjects

at homozygous and heterozygous states. Homozygous patients were characterized by macrocephalic and multiflagellate spermatozoa.

In 2011, Ben Khelifa et al. [21] studied two brothers from Tunisian descent who presented typical macrozoospermia with a few nonmegaloheaded spermatozoa. Molecular analysis revealed the presence of a new heterozygous variant, c.436-2A $>\mathrm{G}$, identified in both patients. This mutation is located in the acceptor consensus splice site of exon 5 . These results indicate that AURKC molecular analysis of patients with large-headed spermatozoa should not be stopped in the absence of a homozygous recurrent mutation on exon 3 but complete sequence analysis should be performed. The same authors in 2012 have identified a novel nonsense mutation in the AURKC exon 6 gene, p.Y248*, in 10 unrelated individuals of European $(n=4)$ and North African origin $(n=6)$ [23]

In Tunisia, Ghédir et al. [25] evaluated the frequency of c.144delC mutation among infertile and control populations and showed that this mutation is relatively less frequent in the Tunisian population $(0.4 \%)$.

Ounis et al. [27] have also carried out molecular analysis for the AURKC gene in patients with typical macrozoospermia and found 11 patients with this frameshift mutation among the 14 Algerian patients studied.

Furthermore,Chianese etal.[28] screened 3 patients with macrozoospermia for c144del C mutation and found that the two macrocephalic patients with the North African origin (Moroccan) carried the c.144delC mutation. The other patient (Spanish origin), as well as his brother, were homozygous for the p.Tyr248* (c.744C>G) mutation in exon 6.

Recently, Carmignac et al. [29] found by Sanger sequencing c.144delC homozygous mutations in the AURKC gene in two monozygotic twins presenting macrozoospermia and have recommended that the AURKC gene should be sequenced when the sperm contains $30 \%$ or more of enlarged head spermatozoa, and when a mutation is found, artificial reproductive technology should not be performed.

\section{CONCLUSION}

No mutations have been found in Algerian patients with abnormal spermogramms. However, we were limited by the small sample of patients, and the criteria of selection of patients who must have 
macrozoospermia with a majority of large-headed spermatozoa with up to four flagella, which might decrease the power of our study, and thus, we recommend further larger studies to evaluate the frequency of this mutation in patients and control groups.

\section{ACKNOWLEDGMENTS}

We are grateful to patients for their contribution to this study.

\section{AUTHORS CONTRIBUTION}

Rezgoune Mohamed Larbi: PCR, Sequencing and writing manuscript. Chellat Djalila: recruitment of patients, DNA extraction and critical revision of the manuscript. Abadi Noureddine: Data analysis, Director of the biology and molecular genetics laboratory. Satta Dalila: Director of the cellular and molecular biology laboratory and final approval of the version to be published.

\section{CONFLICT OF INTEREST}

No conflict of interest exists.

\section{REFERENCES}

1. Agarwal A, Mulgund A, Hamada A, Chyatte MR. A unique view on male infertility around the globe. Reprod Biol Endocrinol 2015;13:37.

2. Takeda T, Iwatsuki S, Hamakawa T, Mizuno K, Kamiya H, Umemoto Y, et al. Chromosomal anomalies and sperm retrieval outcomes of patients with non-obstructive azoospermia: A case series. Andrology 2017;5:473-6.

3. Dada R, Kumar M, Jesudasan R, Fernández JL, Gosálvez J, Agarwal A. Epigenetics and its role in male infertility. J Assist Reprod Genet 2012;29:213-23.

4. Sherzay N, Chitakar E. Epigenetics: Effect of environmental factors on human genome. Int J Pharm Pharm Sci 2016;8:1-6.

5. Vaghasia K, Shah ND, Shah PS, Bhatt VM, Shah SC, Rao MV. Karyotypic analysis of chromosomal polymorphism in relation to reproductive failure. Int J Pharm Pharm Sci 2017;9:140-3.

6. Plaseska-Karanfilska D, Noveski P, Plaseski T, Maleva I, Madjunkova S, MonevaZ.Association of the AURKA and AURKC gene polymorphisms with an increased risk of gastric cancer association of the AURKA and AURKC gene polymorphisms with an increased risk of gastric cancer. Balkan J Med Genet 2012;15:31-4.

7. Stouffs K, Seneca S, Lissens W. Genetic causes of male infertility. Ann Endocrinol 2014;75:109-11.

8. Ramgir S, Abilash VG. Genetic and environmental factors involved in human male infertility: A review. Asian J Pharm Clin Res 2015;8:34-3.

9. Halder A, Kumar P, Jain M, Kalsi AK. Genomics: Tool to predict and prevent male infertility. Front Biosci (Sch Ed) 2017;9:448-508.

10. Dieterich K, Rifo RS, Faure AK, Hennebicq S, Amar BB, Zahi M, et al. Homozygous mutation of AURKC yields large-headed polyploid spermatozoa and causes male infertility. Nat Genet 2007;39:661-5.

11. Dieterich K, Zouari R, Harbuz R, Vialard F, Martinez D, Bellayou H, et al. The aurora kinase $\mathrm{C}$ c.144delC mutation causes Meiosis I arrest in men and is frequent in the North African population. Hum Mol Genet 2009;18:1301-9.

12. Mesic A, Rogar M, Hudler P, Juvan R, Komel R. Association of the AURKA and AURKC Gene polymorphisms with an increased risk of gastric cancer. IUBMB Life 2016;68:634-44

13. Kimura M, Matsuda Y, Yoshioka T, Okano Y. Cell cycle-dependent expression and centrosome localization of a third human aurora/ipl1related protein kinase, AIK3. J Biol Chem 1999;274:7334-40.

14. Carmena M, Earnshaw WC. The cellular geography of aurora kinases. Nat Rev Mol Cell Biol 2003;4:842-54

15. Yan X, Cao L, Li Q, Wu Y, Zhang H, Saiyin H, et al. Aurora C is directly associated with survivin and required for cytokinesis. Genes Cells 2005;10:617-26.

16. Bernard M, Sanseau P, Henry C, Couturier A, Prigent C. Cloning of STK13, a third human protein kinase related to Drosophila aurora and budding yeast Ipl1 that maps on chromosome 19q13.3-ter. Genomics 1998;53:406-9.

17. Tang CJ, Lin CY, Tang TK. Dynamic localization and functional implications of Aurora-C kinase during male mouse meiosis. Dev Biol 2006;290:398-410

18. Tang A, Gao K, Chu L, Zhang R, Yang J, Zheng J, et al. Aurora kinases: Novel therapy targets in cancers. Oncotarget 2017;8:23937-54.

19. Avo Santos M, van de Werken C, de Vries M, Jahr H, Vromans MJ, Laven JS, et al. A role for Aurora $\mathrm{C}$ in the chromosomal passenger complex during human preimplantation embryo development. Hum Reprod 2011;26:1868-81

20. Fellmeth JE, Gordon D, Robins CE, Scott RT Jr, Treff NR, Schindler K. Expression and characterization of three Aurora kinase $\mathrm{C}$ splice variants found in human oocytes. Mol Hum Reprod 2015;21:633-44.

21. Ben Khelifa M, Zouari R, Harbuz R, Halouani L, Arnoult C, Lunardi J, et al. A new AURKC mutation causing macrozoospermia: Implications for human spermatogenesis and clinical diagnosis. Mol Hum Reprod 2011;17:762-8

22. El Kerch F, Lamzouri A, Laarabi FZ, Zahi M, Ben Amar B, Sefiani A. Confirmation of the high prevalence in Morocco of the homozygous mutation c.144delC in the aurora kinase $\mathrm{C}$ gene (AURKC) in the teratozoospermia with large-headed spermatozoa. J Gynecol Obstet Biol Reprod (Paris) 2011;40:329-33.

23. Ben Khelifa M, Coutton C, Blum MG, Abada F, Harbuz R, Zouari R, et al. Identification of a new recurrent aurora kinase $\mathrm{C}$ mutation in both European and African men with macrozoospermia. Hum Reprod 2012;27:3337-46.

24. Eloualid A, Rouba H, Rhaissi H, Barakat A, Louanjli N, Bashamboo A, et al. Prevalence of the aurora kinase C c.144delC mutation in infertile Moroccan men. Fertil Steril 2014;101:1086-90

25. Ghédir H, Gribaa M, Mamaî O, Ben Charfeddine I, Braham A, Amara A, et al. Macrozoospermia: Screening for the homozygous c.144delC mutation in AURKC gene in infertile men and estimation of its heterozygosity frequency in the Tunisian population. J Assist Reprod Genet 2015;32:1651-8.

26. Molinari E, Mirabelli M, Raimondo S, Brussino A, Gennarelli G, Bongioanni F, et al. Sperm macrocephaly syndrome in a patient without AURKC mutations and with a history of recurrent miscarriage. Reprod Biomed Online 2013;26:148-56.

27. Ounis L, Zoghmar A, Coutton C, Rouabah L, Hachemi M, Martinez D, et al. Mutations of the aurora kinase $\mathrm{C}$ gene causing macrozoospermia are the most frequent genetic cause of male infertility in Algerian men. Asian J Androl 2015;17:68-73.

28. Chianese C, Fino MG, Riera Escamilla A, López Rodrigo O, Vinci S, Guarducci E, et al. Comprehensive investigation in patients affected by sperm macrocephaly and globozoospermia. Andrology 2015;3:203-12.

29. Carmignac V, Dupont JM, Fierro RC, Barberet J, Bruno C, Lieury N, et al. Diagnostic genetic screening for assisted reproductive technologies patients with macrozoospermia. Andrology 2017;5:370-80. 